\title{
Study on Construction of Practical Teaching System for English Major of Applied Colleges
}

\author{
Cui Li \\ Wuhan Donghu University, Wuhan Hubei, 430212, China
}

Keywords: Applied college, English major, Practical teaching.

\begin{abstract}
The primary mission of teaching for English major in applied colleges is to train practical English talents who not only have good specialized knowledge but also know well the local society, economy and cultural development condition. Under such circumstances, it is extremely important to cultivate the English major students' practical ability in applied colleges. Thus, the English major of each applied college needs to ceaselessly update its teaching concepts and shows the favorable practicalness in the processes of teaching and internship, in the hope of cultivating more excellent English applied talents who can serve the local economic development. This paper deeply analyzed the necessity of building the practical teaching system for English major in applied colleges and emphatically discussed some countermeasures to strengthen the construction of practical teaching system for English major in applied colleges.
\end{abstract}

\section{Introduction}

The English major in applied colleges mainly refers to a language major, which mainly aims to cultivate applied English talents, who can directly serve the local economy and society. As practical teaching can significantly improve English major students' ability to use English language, it is increasingly widely used in more applied colleges. However, the traditional teaching mode has always been used for a long time in China, so there are still some problems to be solved in practical teaching, which is a newly emerging teaching method and is in its initial development stage. Therefore, the management personnel and teachers of English major in applied colleges need to continue explorations so as to find the optimal scheme for practical teaching for English major in applied colleges.

\section{Necessity of construction of practical teaching system for English major in applied colleges}

At present, the English teaching in institutions of higher education in China generally lacks practicalness and fails to achieve the mutual connection with the practical needs of employers in the society. If this situation continues for a long time, college students' employment difficulty will become increasingly obvious. According to the statistics, over two thirds of graduates from an applied college lack the most fundamental cross-culture communication ability. Besides, there are a lot of students who are "deaf and dumb" during communications in English. This situation absolutely cannot adapt to the practical talent need in today's society in China. In view of the continuous reform in Chinese higher education mode and the ceaseless improvement in polices and system in recent years, to better adapt to the teaching need and realize the cultivation of high-quality talents, students instead of teachers have become the core of classroom. Nowadays, it is required to consider students as the main subjects and comprehensively cultivate their abilities of listening, speaking, reading and writing etc. in practical teaching. Then, the role of college students will become more important in a class. Objectively speaking, students need to energetically coordinate 
with teachers, participate in the interactions with teachers, actively participate in practical learning and reach the effects of enlivening the teaching atmosphere and stimulating the learning initiative. However, practically speaking, the English student group's English application ability is rather limited as a whole, so they are not willing to boldly communicate with their classmates in English; for this reason, they even hope to avoid English practical teaching; this is a difficulty usually faced by many teachers for English major in applied colleges during the process of practical teaching. For instance, after a task of practical teaching was put forward, none of the students actively gives a response, resulting in the inadequately warm classroom teaching atmosphere. Thus, English major students' practical ability has an extremely important influence on the effect of classroom, so teachers for English major in applied colleges need to introduce the educational and teaching methods in compliance with students' practical conditions and progressively guide students to participate in practical learning so as to maximally improve students' English practical ability and thus realize the teaching objectives.

\section{Some countermeasures to strengthen the construction of practical teaching system for English major in applied colleges}

\section{Painstakingly change the curriculum setting concepts of English major in applied colleges}

The past teaching concept mainly targeting at examination and assessment has gradually deviated from the correct track of teaching for English major in applied colleges. According to the situation, all applied colleges have successively pushed forward their reform steps in curriculum setting for English major so that the curriculum setting can better adapt to the new thinking of current practical teaching. Firstly, conscientiously break the traditional curriculum setting mode for English major with the teacher as the subject during the curriculum setting so that students can really become the master of English major classroom; guide students to actively get engaged in classroom learning and cultivate college students' ability to use English language, especially the ability of listening, speaking and writing, through the mutual English communications between teachers and students, exhibition of students' achievements and many other links. Secondly, more abundant teaching means should be listed in the new curriculum design. For instance, teachers can use more classroom discussions, group cooperative learning, practical visits and other means so as to provide English major students with more good opportunities to practically use English; this is also an indispensible and important link in practical teaching for English major in applied colleges. Thirdly, for the curriculum setting for English major, it is also required to comprehensively consider the current society's urgent need for applied English talents, add many optional courses concerned such as simultaneous interpretation and translation of English practical writing and painstakingly make the knowledge learned by students in classroom to maximally meet the practical need of society. Only in this way, can a more solid foundation be laid for the implementation of practical teaching by English major in applied colleges.

\section{Improve college students' practical ability by using classroom teaching of}

Teachers' teaching for English major in applied colleges provides services for students' learning. Therefore, teachers need to control the degree of theoretical input and students' participation in classroom teaching, namely students' participation in classroom discussion, analysis and problem solving etc., so as to better cultivate students' English thinking ability during classroom teaching. In the realistic classroom teaching for English major, many students usually neglect students' classroom practice. The course teaching organizers for English major more concern how to give a through and good lecture and how to complete all classroom teaching tasks within the limited time; however, they don't consider how to make students to actively integrate into classroom teaching and how to further expand college student group's thinking ability. Under this teaching guidance concept, many technical ability courses for English major in applied colleges are dominated by teachers' teaching and students' listening; students only have very little time for practice even in oral class. To better improve the English major college student group's language application ability, the author conducted 
a teaching experiment. As shown in the result, through the comparison of classes with more content of practical teaching and classes with more content of theoretical teaching, the students' English speaking and writing abilities in the former is better than those in the latter.

\section{Continuously promote the quality of internship for English major in applied colleges}

Internship, so to speak, is one of the important links for English major in applied colleges to obtain the graduation qualification and the best opportunity for practice before students formally take up work posts. Based on the internship link, college students can better test whether the English knowledge they've learned can be applied well in social practices, know whether their knowledge reserve and abilities can adapt to the practical social needs, better adjust their own learning methods and enhance their sense of responsibility for advancing with times. Besides, they need to work steadfastly and diligently and continuously promote their practical ability.

Firstly, intensify the management strength for internship link of English major in applied colleges. Whether the construction of internship management system for English major in applied colleges is complete and perfect, whether the internship requirements are adequately standardized and whether the execution of systems is in place will directly affect the internship effect of the English major intern group. The internship arrangement for English major students in applied colleges usually is usually different in the mode of internship with other majors due to its particularity. A unit cannot accommodate many English major interns in one place (except the teaching intern of English teachers), so English major interns in applied colleges fully have more difficulties. Nowadays, teachers for English major in applied colleges have rather heavy teaching tasks so it is infeasible to assign many instructors to the internship units to give detailed instructions. It is relatively practical that college English major standardizes the documents concerning internship management, carries out the zero reporting system from the department of internship management for colleges to the department management leaders, persons in charge of teaching and research office and internship instructors etc. in all colleges; namely, implement daily report, weekly report and monthly report etc. to form a one-stop management system. Meanwhile, carry out inspections and patrols at irregular intervals and make concerted efforts with internship units to strengthen inspections and standardize all internship materials for the intern group; in this way, the English major interns who want to practice fraud or be opportunistic will have no opportunity; thus, the internship management for English major in applied colleges can be continuously strengthened and English interns' all qualities can be continuously improved comprehensively.

Secondly, enhance the management validity of internship operation link for English major in applied colleges. The internship of English major students in applied colleges usually relies on instructors' comprehensive instructions and forms a new teaching-learning-research integrated operational mode so that college students can learn and research from practices. The teaching by teachers for English major in applied colleges is mainly that the internship instructors progressively guide students to get more familiar with the actual operational law and flow of the work by using corresponding theoretical knowledge and experience in practical operations based on the specific internship posts. Learning mainly means that English major students in applied colleges gradually understand and use the knowledge in their specific internship posts in internship units under the careful guidance of instructors so that they can work independently. Research mainly refers to that English major students in applied colleges should continuously research all newly emerging issues and thinking modes as well as deeply think how to solve all sorts of problems caught in their realistic work during their practical work practices in the internship units.

\section{Enhance the cross-culture communication ability of college students in applied colleges}

Under the great influence of traditional teaching thoughts in recent years, teachers have always been paying attention to the large-scale training of language knowledge during the teaching for English major in applied colleges of China but neglected the cultivations of the college student group's cultural quality. We can say that English language knowledge is the important foundation for English learning; therefore, one who fails to grasp well English language knowledge cannot meet the needs of 
all communications, let alone expand their own cross-culture communication ability naturally. With single English knowledge and without the support of comprehensive and deep English culture knowledge, one could preliminarily understand the meaning of English language at most but it is difficult for one to attain the goal of cross-culture communication. In view of this, to better implement the practical teaching for English major in applied colleges, it is required to cultivate college students' abilities in vocabulary, grammar and listening etc.; besides, on this basis, students also need to absorb pluralistic nutrient elements so as to continuously improve their English cultural deposits and thus realize the goal of improving their cross-culture communication ability.

\section{Highlight the training of practical teaching ability for English teachers}

In the practical teaching for English major in applied colleges, the teacher is the major executor of teaching, so the level of a teacher certainly will directly affect the final effect of practical teaching for English major in colleges. Because of this, all applied colleges should conduct targeted training for teaching quality and ability based on the specific condition of their respective English teaching staff and the group of English teachers, in the hope of practically helping teachers to continuously enhance their practical teaching ability and better meet the needs of curriculum reform for English major in institutions of higher education. At present, there is a very great improvement space for the practical teaching ability of the teacher group for English major in applied colleges of China; especially, the group of young and middle-aged teachers has high acceptability in practical teaching while the elder English teachers have very rich educational teaching experience and stronger ability. Therefore, when carrying out the teaching ability training for English teachers, colleges need to pay high attention to the full utilization of the characteristics of the above two types of teachers; namely, colleges not only need to let young and middle-aged teachers to drive elder teachers to recognize the urgency of cultivating English major students' practical ability but also need to actively encourage elder teachers to pass on corresponding teaching skills and experience to young and middle-aged teachers. Only in this way, can teachers for English major in applied colleges can maintain a harmonious relationship, help each other in work and promote the continuous improvement in their own practical teaching ability.

\section{Conclusion}

To sum up, the practical teaching for English major in applied colleges is still in the preliminary development phase and all sorts of practical issues are inevitable during the process of specific application, so English educators in colleges need to continuously improve their teaching concepts and ceaselessly enhance their qualities so as to provide a better development platform for practical teaching and popularization. In this way, they can facilitate the continuous improvement in the practical teaching ability of English major in applied colleges of our country and thus cultivate more applied talents of higher levels.

\section{References}

[1] Kong Qianyun. Current situation, problem and rectifying thought on practical teaching for English major in local colleges, Yalu River (version of the second half of month), 2014 (7).

[2] Zhao Shengxue. Cultivation mode and implementation strategies for English talents in applied colleges - taking the English major of Bengfu College for example, Journal of Hubei University of Education, 2015 (3).

[3] Li Guibo. Construction of practical teaching system for business English in applied universities, Journal of Anshun College, 2015 (6). 
[4] Cui Aiting and He Lin. Reform and practice of college English course teaching based on the concept of cultivation of applied talents, Journal of Jilin Engineering Normal University, 2015 (11).

[5] Cheng Ying and Yang Bei. Practical research on methods for public English teaching in application-oriented university experimental class in higher vocational colleges, Journal of Hunan Post and Telecommunication University, 2016 (1).

[6] He Chunyan. Study on problems and countermeasures for reform practices in college English on the background of application-oriented technological transformation, Science \& Technology Vision, 2016 (16). 